\title{
Reflections on the Employment Guidance of College Students in Self-media Era
}

\author{
Li Huijuan \\ Changchun University of Finance and Economics, Changchun China, 130122
}

Keywords: self-media era; college students; employment guidance

\begin{abstract}
This paper focuses on the employment guidance of college students in the era of self-media. Through analyzing the problems encountered in employment guidance in colleges and universities, this paper explores reasonable adjustment measures to promote the smooth development of employment guidance for college students, reduce the negative factors in the employment process of students, promote the smooth progress of various tasks as planned, and improve the quality of student employment.
\end{abstract}

\section{Introduction}

The development of modern science and information technology has accelerated the speed of information dissemination. Since the advent of the media age, university students can receive information at different times and locations through mobile terminals, and their ability to obtain information has been significantly enhanced. However, the current network still has problems in the process of media construction, which affects the smooth development of employment guidance for university graduates, and it must analyze specific issues.

\section{Problems in the Employment Guidance of College Students in Self-media Era}

Network infrastructure construction is the basis for self-media construction. The quality of network infrastructure determines the quality of self-media. However, in the current process of university construction, some colleges and universities have not strengthened their attention to network infrastructure and are affected by the low economic level. There are still a series of problems in the construction of network infrastructure for such schools. Schools cannot formulate a comprehensive plan for the construction of network infrastructure. There is still a certain gap compared to other regions and universities, which affects the quality of information transmission and leads to many problems in the process of media construction. At the same time, in order to keep up with the pace of information technology development, we must pay more attention to the hardware and software update work, and renew them in time. However, under the situation of the shortage of funds in universities, the hardware and software update work may not be carried out in time, resulting in broadband. The speed cannot meet the needs of the college students' employment guidance work in the era of self-media, resulting in the influence of different degrees on the speed of the network during the operation of the media and affecting the normal development of related work. The attitude of relevant leaders in universities is also an important factor affecting their own media construction. In the case of a relatively negative attitude, related work cannot be carried out smoothly according to the plan, resulting in the lack of assistance from the media during the development process. There are many problems in the development process.

Different universities have different focuses and there are certain differences in the orientation of students' training. At present, some colleges and universities do not pay enough attention to student employment. Some colleges and universities do not have a sound employment information network. As a result, in the construction process, colleges and universities only cooperate with companies that have business contacts, and they have relatively few connections with other companies, which cannot meet the needs of cultivating students' all-round development. At the same time, the construction of the university's employment tracking system is still not enough. When there is a conflict between students and employers, universities cannot give them full support. This has led to 
many problems in the actual work of students. With the rapid development of the Internet, students use the Internet to send resumes to all types of companies. However, their online application approval rates have always been low. Students' enthusiasm for employment is easily hit, affecting the overall development of students. At last, there are some problems in the exchange of employment information between universities and colleges, and there are some problem in the exchange of experience, the information obtained is relatively unitary, and the waste of employment resources is more serious.

With the development of the network economy and self-media era, higher requirements have been put forward for the overall quality and professional quality of the employment guidance staff in universities, but the quality of the staff work in the universities employment guidance office is uneven. Under the impact of the self-media era, many workers are unable to grasp the new knowledge of employment guidance timely. In the process of student employment guidance, such staff provide less help. On the other hand, the development of employment guidance in universities has been stagnant for a long period, employment guidance personnel are relatively few, and the students services are relatively small, affecting the development of all types of work.

Since the arrival of the media era, students have received a lot of new ideas in the employment process, and their outlook for choosing jobs has also changed. After graduating, students are more concern about the company, their development prospects, and their own ability assessments. They are less selective about work units and cannot position themselves accurately. As a result, students' employment is slow, and employers cannot find the needed jobs in time. This influence the development of each other. Currently students are unwilling to start from scratch under the influence of utilitarianism and other thoughts. They are dismissive of some jobs that need to go deep into the grassroots, and they just started graduating and compared the company's welfare and salaries, and attached great importance to material enjoyment. Under the influence of this type of thinking, most students pursue "put things right once and for all" after graduating, and the enthusiasm of student work has decreased significantly, which not only reduces the student's employment rate, but also affects the student's long-term development.

\section{Suggestions for the Development of College Students' Employment Guidance in Self-media Era}

Since the media has played an important role in the employment of college students and in many other aspects, it has play an important role on the long-term development of students. Therefore, colleges and universities must pay more attention to the construction of self-media, and by increasing capital investment to improve the broadband speed and software and hardware configuration within the university, promote the need to adapt to the rapid development of information technology, and promptly carry out follow-up related work. Through the establishment of professional project development plans and so on, the organization of self-media in colleges and universities will be organized and guided to improve work efficiency.

The employment guidance office of the university should pay more attention to the dissemination of employment information, adjust working concept in time, change its traditional thinking, and carry out information dissemination actively. Relevant units of college employment guidance should promptly establish the college's own employment guidance public WeChat official accounts, push new recruiting and employment information to the students regularly, and conduct research on the issues in the work process and possible problems, and timely Students promote practical advice, promote students to apply successfully under guidance, and how to play their own value in the company. At the same time, the WeChat official accounts and self-media platform established by the Graduate Employment Guidance Office should also pay close attention to changes in the country's employment policies, combine the practicality of the policy analysis profession, and provide students with professional development advice and other content to promote student development. When college graduates are looking for a job, they are affected by their different development goals. Students are generally dispersed. Colleges must strengthen the requirements for counselors, promote their timely gathering, teach students the relatively work 
knowledge, and promote students to achieve new goals. The employment guidance staff of college students should also perform systematic propaganda and education to students as much as possible, avoiding the problems of student employment knowledge and so on. Search for work under the guidance of a comprehensive and logical thinking on employment to promote students to achieve new development.

At present, in the process of the development of college student employment guidance, students are not able to enjoy employment guidance services in a timely manner due to a variety of factors. There are many problems in the actual development process. Many students cannot grasp the opportunities and lead to the development of various tasks. There are many problems in the process. To this end, colleges and universities must pay more attention to the convenience of employment guidance and establish a more complete employment guidance mechanism for university graduates. With the support of the network, college employment guidance staff can timely observe the general environment of the job market, grasp the current problems in the employment and employment links, and promote various tasks in accordance with plans to promote high-quality and promising employers to students. Students are successfully employed. At the same time, in view of the current two-way employment situation, colleges and universities must pay more attention to school-enterprise cooperation work, and carry out activities such as school-enterprise cooperation with major companies to evaluate the overall quality of students and deliver talents to enterprises in time. This enables students to have a deeper understanding of the enterprise during their contact with the company. The company can also further inspect the students, realize further understanding in the process of mutual observation and promotion, and facilitate the employment of students in the future. In order to reduce the burden of process in the employment process of university students as much as possible, institutions such as the University's Employment Guidance Office must strengthen the emphasis on student information adjustment, help students coordinate the transfer of household registration, help students solve obstacles in the non-work content that arise during the recruitment process, and make students concentrate on looking for work, reduce the negative impact of other factors on student development, and increase student employment.

In order to improve the employment rate of students, colleges must pay more attention to resource sharing. Especially in the context of rapid development of the self-media, colleges and universities can strengthen their connections with each other, adjust their problems encountered in the work process, and exchange and share with other schools to develop new solutions. To provide each other with more work experience, so that it can be more reasonable to carry out student employment guidance and other activities, can effectively improve the effectiveness of student employment guidance. At the same time, colleges can also use self-media to conduct online exchanges with enterprises to keep abreast of the company's development status and employment needs, and provide professional students to enterprises. Under the influence of the era of the self-media, the exchanges between colleges can strengthen the sharing of resources, and the convergence of schools and companies will also be closer, which will be of great significance to improving the employment rate of college students.

In the process of finding a job, if college students have sent a large number of resumes but have received very few responses, it is easy to generate emotions such as self-restraint and self-abnegation, which will affect their follow-up job search process. Serious people may even have more serious inferiority complexes and affect their health. For this reason, colleges must pay attention to psychological counseling for college students' employment, and disseminate candidates' successful experience and encouraging words in time through self-media WeChat official accounts. At the same time, college counselors must also strengthen the connection with the students, open up the problem students, make them relaxed, and correctly deal with the problems encountered in the process of finding a job. Through a variety of efforts to promote the smooth development of college students.

\section{Conclusion}

There are many problems in the employment guidance of college graduates. Under the impact of 
self-media, the problems they face will be more extensive, affecting the smooth development of student employment. Colleges must pay more attention to the construction of self-media, improve the school's development environment, and provide students with effective employment information and employment experience, and promoting students ' orientation in employment.

\section{Acknowledgment}

Research name: research on application strategy of self-media in college students' employment guidance (NO.JJKH20171021JY).

\section{References}

[1] Zhou Liang, Yang Zhaoliang, Wan Yuanyuan. How to carry out employment guidance for counselors in the media age [J]. Western China Quality Education, 2016, (23): 274-274.

[2] Li Baoxin, Li Xing, Wang Yaxue, etc. The Application Survey and Practical Research of Self-media in College Students' Employment [J]. New media research, 2015, (23):27-29.

[3] Xu Jun. Study on College Students' Employment Guidance [J]. Charming China, 2017, (35): 164. 